DOI: https://doi.org/10.47405/mjssh.v5i1 1.551

\begin{tabular}{|c|c|}
\hline 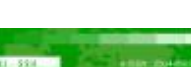 & Malaysian Journal of Social Sciences and Humanities (MJSSH) \\
\hline Malaysian Joumal of & Volume 5, Issue 11, November 2020 \\
\hline (av-ssti) & e-ISSN : 2504-8562 \\
\hline & $\begin{array}{l}\text { Journal home page: } \\
\text { www.msocialsciences.com }\end{array}$ \\
\hline
\end{tabular}

\title{
Fundamental Applications of Mathematics in Agriculture and Cultural Heritage in Daily Life of Melanau Tellian, Mukah, Sarawak: An Ethnomathematics Review
}

\author{
Suffina Long ${ }^{1}$, Yahutazi Chik ${ }^{2}$ \\ ${ }^{1}$ Faculty of Computer and Mathematical Sciences, Universiti Teknologi MARA, Mukah Campus, Sarawak \\ ${ }^{2}$ Faculty of Plantation and Agriculture, Universiti Teknologi MARA, Mukah Campus, Sarawak \\ Correspondence: Suffina Long (suffinalong@uitm.edu.my)
}

\begin{abstract}
Mathematics has been measured as a neutral subject and not related to any culture or a society. Learning Mathematics in the modern education system nowadays is an adoption from many parts of the world. This ethnomathematics review is to discover culture and mathematics related to the daily life people of Melanau Tellian in Mukah Sarawak. This study uses a qualitative approach, ethnographic methods and principal such as observation, interview, collecting data and documentation from the fieldwork. The findings showed that the foundation of the Melanau people in Tellian Mukah is essentially based on numbers or Mathematics. It shows in the Melanau's belief system, social system, traditional games, architecture and in daily practice and tradition. There is a line of relationship between mathematics and culture in this study which can be an initial point for further preservation of Melanau Tellian cultural heritage.
\end{abstract}

Keywords: ethnomathematics, cultural, heritage, agriculture, Melanau

\section{Introduction}

Ethnomathematics derived from the words of "ethno" and "mathematics". Ethno from Greeks word define as nation, culture, race or people, while mathematics is a study of measurement, relationships, sets, sorting, summing and modelling which involves numbers and symbols. The study of the measurement, relationships, and properties of quantities and sets, using numbers and symbols. Arithmetic, algebra, geometry, and calculus are branches of mathematics (Greer \& Mukhopadhyay, 2015; Powell \& Frankenstein, 1997). Ethnomathematics define as a cultural study of mathematics and incorporates mathematical ideas and procedures practiced by the members of distinct cultural groups, which are identified not only as indigenous societies but as groups of workers, professional classes, and groups of children of a certain age group as well (D'Ambrosio, 1985; Rosa \& Orey, 2016). Melanau is one of ethnic group in Sarawak and can be classified into ten group-wise mostly according to geographical location which consists of Melanau Matu-Daro, Melanau Pulau Bruit, Melanau Dalat, Melanau Oya, Melanau Mukah, Melanau Belawai-Rajang, Melanau Rejang, Melanau Balingian Melanau Bintulu, and Melanau Miri. Each different Melanau has its own dialect which can cause challenges in communication among Melanau community. Mukah, a coastal town is one of division in Sarawak. Also known as The Melanau Heartland, the majority population in Mukah is Melanau. In Melanau Mukah society, they have their own number system and even have their own months. Mukah is a part of the three major growth nodes of Sarawak Corridor of Renewal Energy (SCORE) program. It has been announced by the former Chief Minister in 2009 where it focuses on Smart City, Services 
Hub and Research and Development (Hashim and Echoh, 2015; RECODA, 2016). Therefore, it is suitable to do ethnomathematics research in Melanau society in Mukah.

\section{Literature Review}

\section{Ethnomathematics}

Ethnomathematics is a field of study that integrate between mathematics and culture. The study of ethnomathematics gives meaning of how people within various cultural groups develop techniques to explain and understand their world in response to problems, struggles and endeavors of human survival (d'Ambrosio, 2001). Ethnomathematics as the application of mathematics by various cultural groups defined in terms of gender, occupation, age, and ethnicity (Shirley, 1992). The goal of ethnomathematics is to present an accurate history of mathematics, use a variety of examples to solve problems from a variety of cultures, and recognize that learning mathematics is a unique process for each individual (Arismendi-Pardi,1999). Septianawati, Turmudi and E Puspita (2017) stated in the result of their study that the relevancy between mathematics and local culture can increase public perception of the important of using mathematics in daily life. Every culture has its own way of mathematical measuring and thinking which is part of its inheritance and the result of the struggle for its survival (Balamurugan, 2015). For this research, it will look deeper on how Melanau Mukah society and culture use mathematics in measuring and how it converts to current standard measurement.

\section{Unit of Measurements}

Unit of measurement define as magnitude of a quantity and adopted by convention or by law. For the same quantity, it is used as a standard measurement (IUPAC \& OIML, 2012). The quantity of unit can be conversed to different units of measurement for the same quantity. It can be calculated through multiplicative conversion factors. Systeme International or we denote as SI was from a French word which describe the International System of Units is the modern form of the metric system. It is being used worldwide and introduced in school curriculum as a system or unit of measurement. There are seven units of measurement in a basic set of International System of Units. The SI base units for measurement of length is meter, measurement of mass is kilogram, measurement of time is second, measurement of electric current is ampere, measurement of temperature is kelvin, measurement of intensity is candela and measurement of substance is mole.

\section{Mukah Division}

Melanau is the fourth largest ethnic in Sarawak with the population of 120000 people and the majority of the Mukah population are Melanau. According to Dris (1997), Melanau ethnic can be defined as “... a definite and concrete group speaking different Melanau dialects, sharing a common custom and culture, mainly residing in coastal areas between Kuala Rejang in South-west and Kuala Baram in the North-east". Melanau society are mainly divided into Muslim and Christian religion although some of them are still practices animism and are called Melanau a-likou (people of the river) referring to the traditional belief of the indigenous peoples of Melanau. There are similarities between Sarawak Malays and Melanau society in terms of way of life but they significantly differ especially in language, tradition and customs. Melanau dialect is totally different than the local Sarawak Malay dialect. In addition, to make things more complicated, different regions within the same district speaks Melanau dialect differently (Zakaria, 2006).

In terms of economics activities, in the past, the Melanau society were blacksmith, carpenter, skillful boat makers with their main occupation as a fisherman or sago palm planters. Historically, as early as four hundred years ago, the Sultan of Brunei appointed Melanau representatives to control the revenue from the sago business activity in the central coastal regions especially at Oya and Mukah rivers (Morris, 1978). Nowadays, there are still Melanau community work as fisherman and sago planters, however due to improvement of education, many Melanau shifted their traditional economy to more secured and salaried jobs in government and private sectors respectively. 


\section{Methodology}

This research uses qualitative approach employing face to face in situ interviews after research sites have been identified. The informal structured interview concerning the unit of measurements to uncover the ethnomathematics in Melanau community in Mukah. Ethnomathematical research study the cultural practice, mutual interrogate, interview and collecting information from the society (Alangui, 2010). Ethnography methods will be used in this study to discover mathematical idea, especially in units of measurement practice by Melanau society in Mukah, Sarawak. The field work of this research will do the observation, interview, collecting and documentation the data. The data will be presented in a comparison table with measurement analysis. Then, running validity test in term of credibility, transferability, dependability and confirmability before summarizing the conclusion. The research will be done in eight villages in Mukah namely, Kampung Sesok, Kampung Tellian Laut, Kampung Tellian Daya, Kampung Tellian Ulu, Kampung Petanak, Kampung Jebungan, Kampung Seberang and Kampung Sungai Alo in Mukah, Sarawak and expands to Kampung Tenom, Kampung Sungai Ud and Kampung Medong in Dalat area and also Oya area. These chosen villages are known for sago plantation, oil palm plantation, fishing area, construction and manufacturer such as house construction, tibow, baban, tapow, boat, coffin (for Melanau Christian and Melanau Likou) etc.

Ethnomathematical research studies the cultural practice, mutual interrogate, interview and collecting information from the society (Alangui, 2010). Ethnography methods were used in this study to discover mathematical idea practices by Melanau society in Mukah, Sarawak. The fieldwork of this research involved observation, interview, collecting and documentation of data. Therefore, this study uses a qualitative approach employing face to face in site interviews after research sites have been identified. Subsequently, informal structured interview sessions with informants concerning the unit of measurements to uncover the ethnomathematics in Melanau community in Mukah were conducted. There were four (4) informants involved directly in this study who are selected from Kampung Tellian Daya, Kampung Tellian Ulu and Kampung Sesok, Mukah, Sarawak. These areas were chosen as the study sites because of the historical background of Tellian as the heartland of Mukah and due to the commitment of the informants towards Melanau heritage preservation.

\section{Result}

Measuring is a daily activity by people around the world. In Melanau Mukah society, measuring involving length, volume, weight and area. Units of measurement use in Melanau Mukah society before standard measurement been introduced in modern curriculum was depends on traditional measuring instrument. The urbanization of Mukah division also affected the Melanau community in their relationship, communication and education in the society. To date, Melanau Mukah society practices the International Units of measurement (Systeme International, SI) with the intention to standardize and facilitate the measurements with only one standard unit for all community around the world. Units of measurement use in Melanau Mukah such as, kati, ela, depa, jengkal, ika, pajak, pa'un and yet to be discovered in this research will gives benefit to younger generations. This heritage can bridge the gaps between younger and older generations in Melanau Mukah society. Despite bridging the generation gaps, information collected in this research also can be a tool for native language preservation from extinction.

\section{Numbering system}

Data from Figure 1 shows that Melanau Tellian people use mathematics or basic calculation in everyday life. 
Figure 1: Data collected from the interview

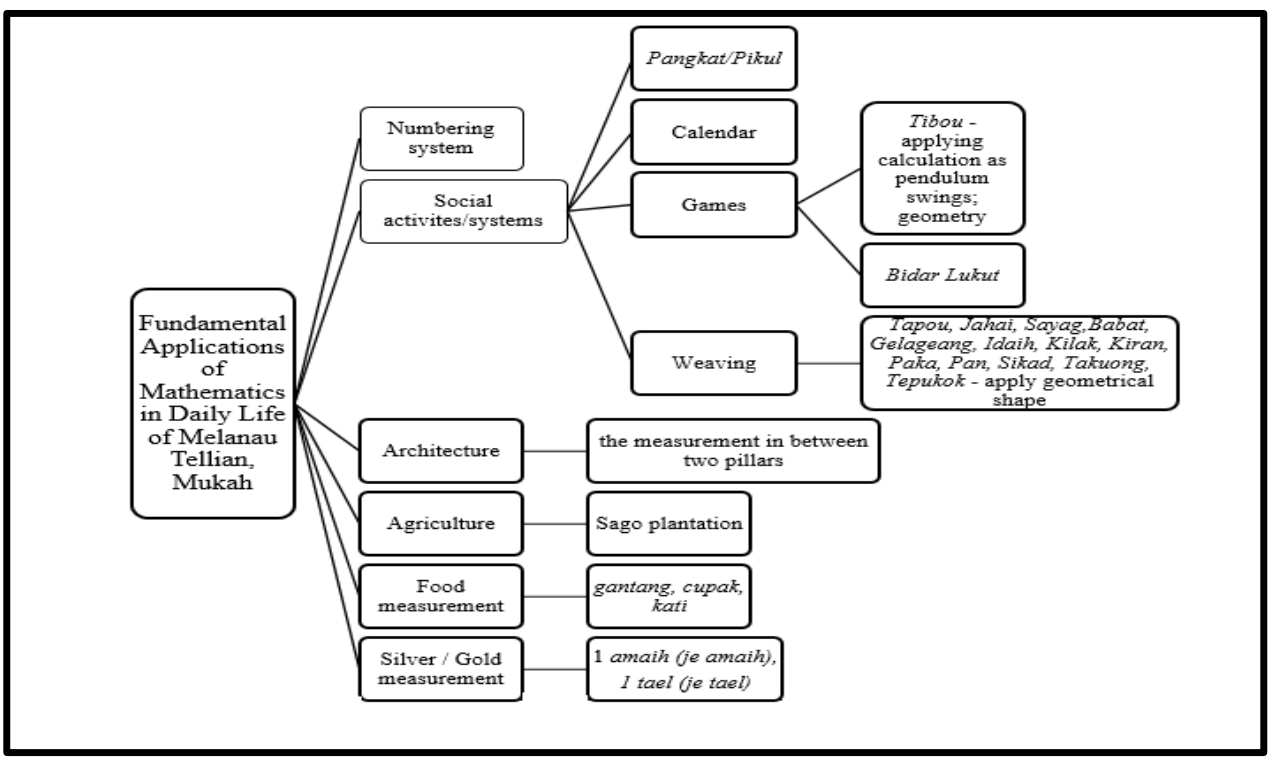

Melanau people have their numbering system. Numbering in the Melanau community is shown in Table 1 below:

Table 1: Numbering in Melanau

\begin{tabular}{cc}
\hline 1 & Satu (ja/je) \\
2 & Dua \\
3 & Telou \\
4 & Pat \\
5 & Lima \\
6 & Nem \\
7 & Tuju \\
8 & Ayan (lapan) \\
9 & Ulan (Sembilan) \\
10 & Pelu'en \\
\hline
\end{tabular}

\section{Social Activities and System}

\section{Hierarchical/Ranking System}

In the Melanau social system, they have their hierarchy or ranking social system called Pangkat or specifically called as Pikul. Previously, the Brunei Sultanate controlled Melano Kingdom. At present, every individual in the Melanau society of Mukah have been grouped into different ranks which are sembilan (9) pikul, tuju' (7) pikul, lima (5) pikul and dipen (Liza, 2001). However, after the Brunei Sultanate involved in ruling Sarawak, the hierarchical and ranking system in the Melanau society also being influenced with the Brunei Sultanate ranking system. They introduced the highest rank in this hierarchy which is lima belaih (15) pikul and being called as Pengiran. This Pengiran title is only given to Muslim Melanau from the Brunei Sultanate. This ranking system has influenced in the engagement ceremony, wedding ceremony and funeral. The following are various hierarchical and ranking system in the Melanau society. 


\section{Bangsa Pengiran}

The highest rank in the hierarchy is known as Bangsa Pengiran but only existed after Brunei Sultanate representative came to Sarawak. This rank evolved through marriage in between Pengiran and Melanau women and the offspring have the title of Awang, Dayang or Pengiran. They entitled the dowry of 15 pikul tembaga' kunieng (brass).

\section{Bangsa Sembilan Pikul (A-Matahei)}

This is the actual highest rank in Melanau society. A-Matahei which means a minister has their tanda pangkat or rank insignia such as the flag and the cannon. They probably hold the most important position from politics to economics in Melanau society. As for dowry in wedding ceremony, they entitled of 9 pikul tembaga' kunieng or 9 amaih emaih which equivalent to 63 grams of gold in modern-day. However, nowadays due to the rise of the gold price, the exact value of this 9 amaih emaih is replaced with any equivalent value based on mutual agreement between the family of the brides.

\section{Bangsa Tuju' Pikul}

This group can be described as the middle class of the hierarchy. They are free to manage their life and family without interference or oppression from the upper class. They are also free to find their earning to improve their economic status.

\section{Bangsa Tuju' Betirih (Lima Pikul)}

This group is considered as knights for the Bangsa Sembilan Pikul (A-Matahei) and they also received oppression from the upper class.

\section{Dipen}

This is the lowest rank in Melanau society. They are the slaves for the upper class or known as kulad bernukan. There are two types of dipen which are known as dipen dagen lebok (live with the landlord/hostess) and dipen ga' luer (allowed to live in their house). However, this slavery system was illegitimate during Rajah Brooke era in 1928 when they banned all the slavery system in the society.

\section{Annual Calendar}

Melanau people are mostly sailors, traders, fishermen and seafarers. In order to survive in the deepsea, they do the calculation based on the stars and wind's direction and they come up with their calendar which starts around March and ends in February next year. The months in the Melanau's calendar is their guidance for their daily activities. One year in the Melanau calendar consists of 12 months where each of the months consists of 30 days and like the modern calendar system. Melanau beliefs in guardian spirits that guide them on the calculation of the constellation, rise and set of the sun, moon and stars. The calendar as their guide for their daily works such as agriculture includes planting activities, fishing, house building, travelling, wedding ceremony and others. Following are the months in the Melanau calendar (Johan, 2008).

Table 2: The summary of Melanau calendar 
March

April

May

June

July

August

September

October

November

December
Bulan Pengejin (The month of the spirits)

The beginning of the Melanau calendar/year.

Due to inclement weather, Melanau people are facing difficulties to go out for work especially for fishermen. At the end of this month, they will build a huge swing called Tibou and make the offerings called Seraheng for Kaul ceremony. This purpose of this ceremony is to seek the blessing from their god or Ipok.

Bulan Pengelaweh Umik (The month of the lesser clear water)

The second month of the Melanau calendar.

It is believed that this month where all the fish will come down to the sea after the Kaul event and it is time for fishermen and the rest of the Melanau people to start their work.

Bulan Pengelawah Ayeng (The month of the greater clear water)

The third month of the Melanau calendar.

The peak of the fishing season and the time for Melanau fishermen to catch and store more fish.

Bulan Paka Umik (The month of the rise of the lesser stars)

The fourth month of the Melanau calendar.

Seven sister's constellation appears, and the planting season starts.

Bulan Paka Ayeng (The month of the rise of the greater stars)

The fifth month of the Melanau calendar.

The seven sister's constellation high and the three sister's constellation appears in the sky.

Due to the strong wind, all farming and fishing activities stop.

Bulan Pelepa' (The month of plentiful)

The sixth month of the Melanau calendar.

The second fishing season where the sea is calm and no longer strong wind. The fishermen will catch plenty of fish to prepare for the coming longer monsoon season.

Bulan Pegalan (The month of the north star)

The seventh month of the Melanau calendar.

The sea is still calm but there are only little fish to catch on. It is a taboo for Melanau people to get married in this month because they believe that the marriage will get cursed and the brides will face difficulties to make a living.

Bulan Suwah (The month of the waves)

The eighth month of the Melanau calendar.

The third and final fishing season. The farmer will start planting rice and sago palm.

Bulan Pidai (The month of the waves)

The ninth month of the Melanau calendar.

The beginning of monsoon season or they called is as musim suloh. The end of the fishing season and the last time for fishermen to go out to the sea.

Bulan Penangaih (The month of revival)

The tenth month of the Melanau calendar.

The flowers and fruits bloom in the jungle. 


January
$\begin{aligned} & \text { Bulan Pemalei (The month of taboo) } \\ & \text { All activities such as marriage, fishing, planting, house construction etc } \\ & \text { are not allowed during this month because the Melanau believes it is an } \\ & \text { ill fortune month. }\end{aligned}$
Bulan Pengesiseng (The month of the gills)
The twelfth month and at the end of the year for the Melanau calendar.
The heavy rain will blow the flowers off the tree and the strong wind
blew the branches and the fronds of sago palms.

\section{Architecture or house construction}

In architecture or house construction, originally, Melanau people live in a longhouse like other ethnic in Sarawak such as the Iban and Bidayuh. This longhouse is built on high a pillar and the foundation or the pilling is from sturdy and hardwood which specifically called as kalang babi. It has a different design due to different architecture period for example, Rumah Limaih and Rumah Serani. The pillar is usually from Sarawak ironwood or known as kayu belian ( $t a$ 'eh). Melanau people will do the calculation very carefully following their beliefs for example, for space (bukak), stairs (tagak), window (terawaeng) etc. The height of the pillar from the land excluding pilling in the ground is about 40 feet high. Meanwhile, in between two pillars, they called it as siraeng. The measurement between these two pillars or one (satu) siraeng is equivalent to 11.5 feet or approximately 3.5052 metres. Now, due to the modernization and to lower the cost, Melanau house is no longer long nor high and they use the regular measurement for the siraeng which is 12 feet long. In addition, according to Melanau beliefs, the length, the width, breadth or even the numbers of pillars must be in odd numbers. There are three basic principles of measurement for the house construction in Melanau, 1) puteri malambai, 2) buaya terjun and 3) dian (durian) sepucuk (Johan, 2009). Generally, puteri melambai measurement principle is highly recommended in the Melanau society since the house brings good fortune while buaya terjun measurement principle is the most avoidance design because of the taboo towards health, wealth and fortune.

\section{Food preparation}

Melanau's traditional food are usually based on sago and fresh seafood because of the geographical factor which is the mangrove and seacoast areas. For an example of the Melanau's traditional food are sago', tebaloi, umai and linut. The ingredients for these foods are very simple, but they need to measure it very carefully. Below is the measurement in the food preparation for Melanau people.

Table 3: Measurement for food preparation

\begin{tabular}{cc}
\hline \multicolumn{2}{c}{ Measurement } \\
\hline Gantang & $\approx 3600$ grams \\
Cupak & $\approx 900$ grams \\
Kati & $\approx 600$ grams \\
\hline
\end{tabular}

\section{Silver or gold measurement}

Lastly, for silver or gold measurement, it is influenced by Chinese traders as shown in Table 4. This gold measurement is also related to Pangkat / Pikul for a wedding dowry. 
Table 4: Silver and gold measurement

\begin{aligned} & \hline Measurement \\ & \hline 1 amaih (je amaih) $\approx 7$ grams \\ &1 ta'el $^{\prime}$ je ta' $\left.e l\right) 5$ times je amaih or approximately 35 grams \\ & \hline\end{aligned}

\section{Agriculture}

In terms of agriculture activities, the ethnomathematics analysis was focused on the cultivation of Sago (Metroxylon sago). Sago was selected since it remains as one of the cultural heritages of Melanau in Mukah as it is consumed by Melanau as a staple food like rice in the form of a starchy paste known as "Linut". Besides that, Sago is also utilized as a raw material for the preparation of traditional biscuits known as "Tebaloi", and also processed as flour locally known as "Lemantak". Data provided by Department of Agriculture Sarawak had shown that the total area planted by small scale sago farmers outnumbered the total area planted by commercial sago plantation with 43,426 hectares and 24,531 hectares respectively. Since most of area planted by small scale sago farmers, the analysis of ethnomathematics on it will be relevant to be considered into account in this study. The following are some of the findings on ethnomathematics in Sago cultivation among Melanau in Mukah.

\section{Site Selection and Preparation for Sago Nursery}

The selection of a sago nursery site depends on several factors such as the soil surface gradient, water resources, sunlight requirement, soil fertility and friability and the accessibility. The nursery site for sago sucker preparation should be ideally flat or gently undulating to and nearby to natural water resources such as river which provide a steady supply of irrigation water. Besides that, the sago nursery should be located in an open space where light is not blocked by tall trees or buildings and any obstacles that give shaded condition. The proximity to road is added advantage especially during the process of transplanting of the seedling and transportation to the field.

\section{Planting Distance of Sago Seedling}

Small scale Sago farmers in Mukah still relied on suckers from wild Sago as sources of Sago seedling. Sago seedlings (anak balau) are placed on top of bamboo raft which are floating on the surface of small pond in the nursery. This process is crucial since it will make sure the sago seedling received adequate water supply and having better growth performance before being transplanted to the field.

Figure 2: Bamboo raft (6 ft x $15 \mathrm{ft}$ ) for the placement of sago seedling (sucker)

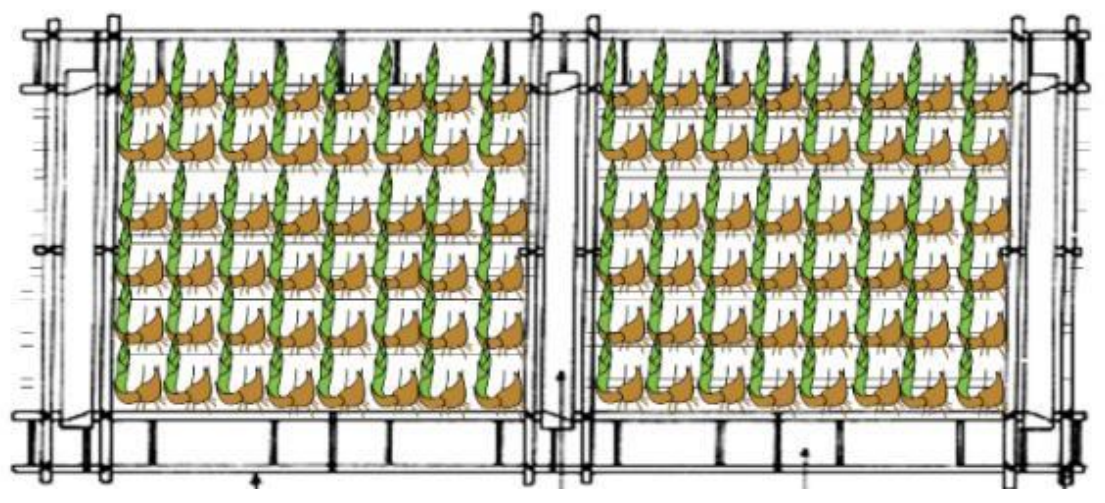


Figure 3: Sample of bamboo raft for nursery preparation of Sago Seedling (Suckers)

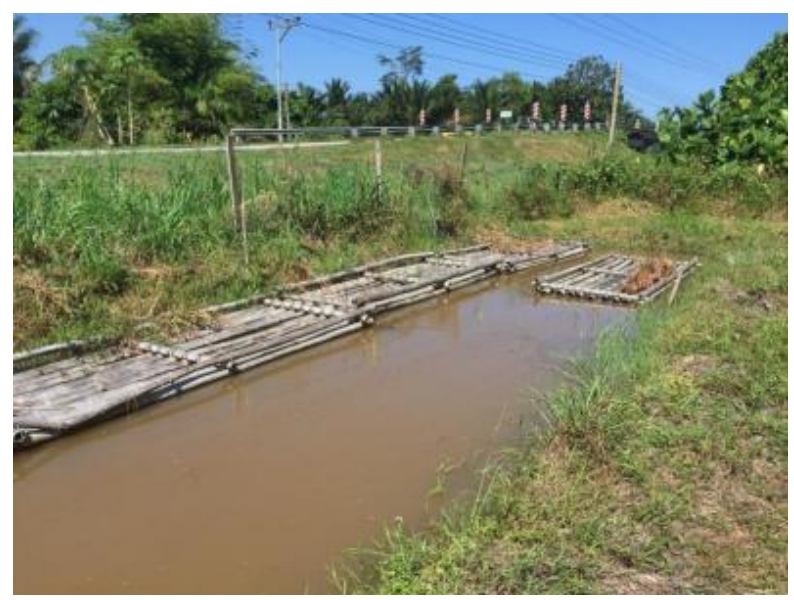

Figure 4: Measurement of distance for sucker in bamboo raft

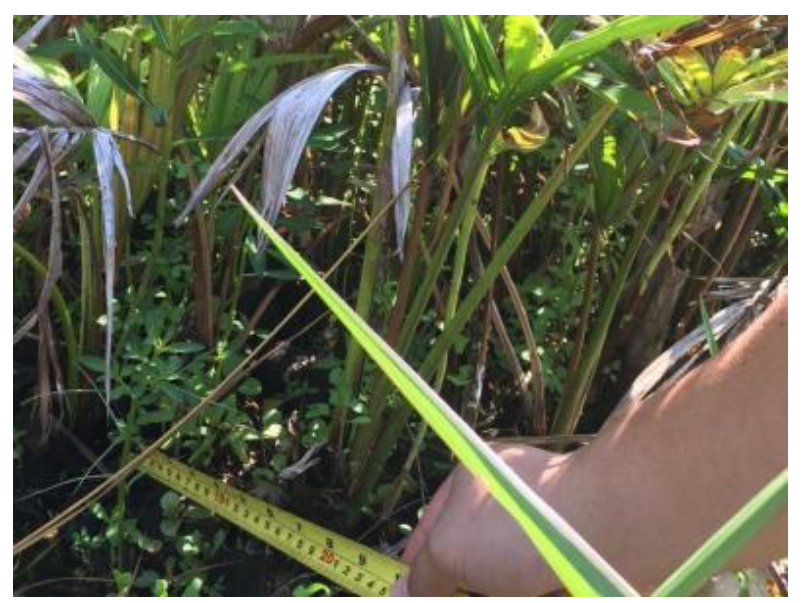

\section{Field Planting of Sago Seedling}

Sago seedling or sucker that already mature will be transplanted to the field after five (5) months raised in the nursery for field planting. The planting density for every 2.5 acres are equivalent to 100 stands of anak balau with the planting distance of 2.5 depa' x 2.5 depa' (15 ft x $15 \mathrm{ft}$ ) following rectangular technique of planting system. The following is the conversion of the unit of measurement for field planting of sago:

1 depa' equivalent to 6 feet. In between anak balau 2.5 depa' $=15$ feet. Therefore, the calculation as below:

$\frac{15 \text { feet } \times 12 \text { inches } \times 2.54}{100 \mathrm{~cm}}=4.572$ meter 
Figure 5 The distance for field planting of sago

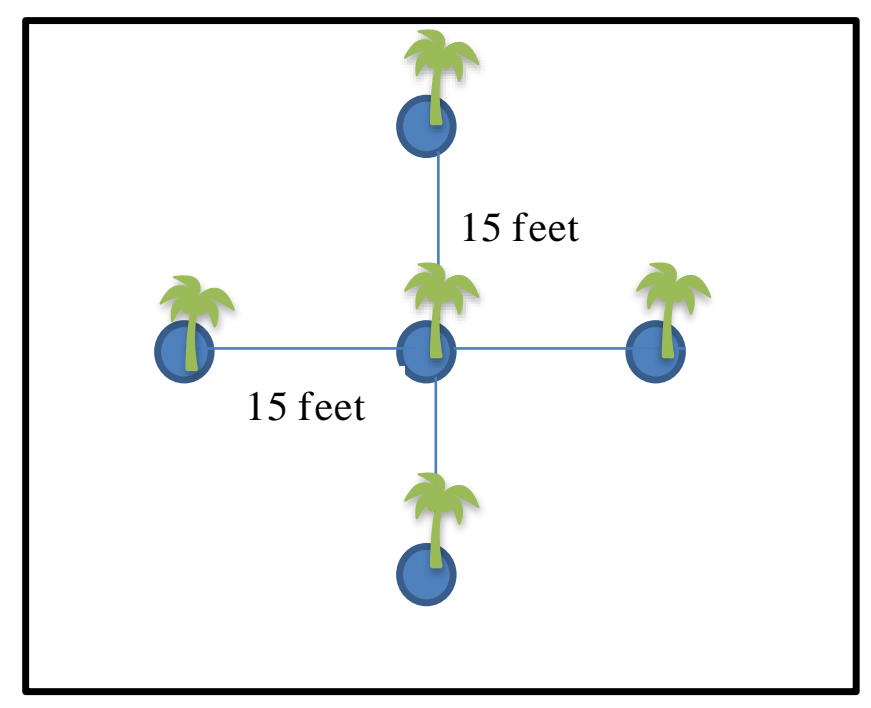

\section{Conclusion}

From the findings, it can be concluded that the Melanau people in Tellian Mukah highly valued Mathematics applications in their daily life which practiced in social ranking, house construction, food preparation, weaving and silver and gold measurement. However, due to modernization and urbanization, the application of mathematics in their daily life is overlooked and forgotten by the younger generation and gradually begin to lose their language, culture, heritage and identity of Melanau.

\section{References}

Alangui, W. V. (2010). Stone walls and water flows: Interrogating cultural practice and mathematics (Doctoral dissertation, ResearchSpace@ Auckland).

Arismendi-Pardi, E. J. (1999). What Is Ethnomathematics and Why Should We Teach It? Crossing Cultures: Communicating through the Curriculum.

Bahauddin, Azizi \& Mustika Syaheeda Awg Musadat, Dyg. (2018). The Traditional Architecture of the Melanau Tall Longhouse, Mukah, Sarawak. SHS Web of Conferences. 45. 01002. $10.1051 /$ shsconf/20184501002.

Balamurugan, M. (2015). Ethnomathematics; An Approach for Learning Mathematics from Multicultural Perspectives. Int. J. Modn. Res. Revs, 3(6), 716-720.

d'Ambrosio, U. (1985). Ethnomathematics and its place in the history and pedagogy of mathematics. For the learning of Mathematics, 5(1), 44-48.

d'Ambrosio, U. (2001). What is ethnomathematics, and how can it help children in schools?. Teaching children mathematics, 7(6), 308.

Dris, A. J. (1997). An Overview: The Cultural Future of The Melanau Community. The Sarawak Museum Journal, 47(2), 299.

Greer, B., \& Mukhopadhyay, S. (2015). Honoring diversity in intercultural mathematics education.

Hashim, N. H., \& Echoh, D. U. (2015). An Identification of the Likely Policy Consequences of the Sarawak Corridor of Renewable Energy (SCORE) on the Affected Agricultural Areas in Central Sarawak. Proceedings of Universiti Sains Malaysia, 216.

IUPAC, B., \& OIML, I. (2012). International Vocabulary of Metrology-Basic and General Concepts and Associated Terms. 
Johan (2008). The Melanau Calendar. [online] Johan1960.blogspot.com. Available at: http://johan1960.blogspot.com/2008/05/melanau-calendar.html [Accessed 28 Aug. 2019].

Johan (2009). Melanau Construction Technology. [online] Johan1960.blogspot.com. Available at: http://johan1960.blogspot.com/2009/10/melanau-construction-technology.html [Accessed 28 Aug. 2019].

Liza, L. (2001). Etnobotani Dalam Perubatan Masyarakat Melanau. Undergraduate Thesis. Universiti Malaya.

Malthe-Sorenssen, A. (2015). Units and Measurement. In Elementary Mechanics Using Matlab (pp. 31-41). Springer International Publishing.

Morris, H. S. (1978). The Melanau. In King, V. T. (Ed.). (1978). Essays on Borneo societies (No. 7). Oxford University Press.

Nasir, N. I. S. (2002). Identity, goals, and learning: Mathematics in cultural practice. Mathematical thinking and learning, 4(2-3), 213-247.

Newell, D. B. (2014). System of Units. Physics Today, 67(7), 35.

Powell, A. B., \& Frankenstein, M. (Eds.). (1997). Ethnomathematics: Challenging Eurocentrism in mathematics education (p. 63). Albany, NY: State University of New York Press.

RECODA. (2017). Sarawak SCORE Mukah Smart City. Retrieved July 5, 2017, from http://www.recoda.com.my/score-areas/sarawak-score-mukah

Rosa, M., \& Orey, D. C. (2016). State of the art in Ethnomathematics. In Current and Future Perspectives of Ethnomathematics as a Program (pp. 11-37). Springer International Publishing.

Septianawati, T., \& Puspita, E. (2017, February). Ethnomathematics study: uncovering units of length, area, and volume in Kampung Naga Society. In Journal of Physics: Conference Series (Vol. 812, No. 1, p. 012021). IOP Publishing.

Shirley, L. (1992). Special Interest Group on Curriculum and Classroom Applications. International Study Group on Ethnomathematics, 7(2), 2.

Stathopoulou, C., \& Appelbaum, P. (2016). Dignity, Recognition, and Reconciliation: Forgiveness, Ethnomathematics, and Mathematics Education. International Journal for Research in Mathematics Education, 6(1), 26-44.

Yusuf, M. W., Saidi, I., \& Halliru, A. (2010). Ethnomathematics (A Mathematical game in the Hausa culture). International Journal of Mathematical Science Education, 3(1), 36-42.

Zakaria, Z. F. (2006). A trip to Mukah. Malaysian Family Physician, 1(2 \& 3), 2. 